\title{
Radical Rethinking Needed in University Science
}

"UNLESS the quality of research (in British universities) puts it in the "world league' the case for supporting it from public funds is weak." This is one of the statements made in a report published this week by the British Association for the Advancement of Science (Higher Education and Scientific Research, BAAS, Fortress House, Savile Row, London W1X 2AA, 30p).

The report, the first to be published by the British Association in a new series, is the result of the deliberations of a study group set up under the chairmanship of Lord Ashby to discuss the implications for scientific research of the white paper, Education: A Framework for Expansion, published in 1972.

The study group expresses concern that research was not given sufficient consideration in the white paper-the word research, it is pointed out, is only mentioned once in the document. The study group observes that this is in spite of the fact that by 1977 there will be 52,000 postgraduates in British universities, 20,000 of them being scientists and probably 15,000 of these engaged in research for higher degrees.

Universities should remain as centres of scientific research, says the study group, and "it would be a calamity for science in Britain, as well as for higher education, if the government's plans for expansion underestimated this need". Although supported research in Britain should be of international standard, according to the study group, this does not mean that universities should concentrate entirely on research to the detriment of other activities. Those university teachers who are not gifted research workers should not desist from the "pursuit of knowledge," says the report, "but rather ... not all those who pursue knowledge should feel under an obligation to carry out research leading to original publications, or should expect their activities to be financed by grants from research councils or the like".

The viability of research departments with small numbers of graduate students is also called into question in the report. Research students benefit from contact with each other, and facilities for formal postgraduate teaching may be lacking in small departments. These are put forward as reasons why larger departments are to be preferred. Of the sixty or so university physics departments which receive Science Research Council studentships almost one-third receive five or fewer studentships (nuclear physics departments excepted)

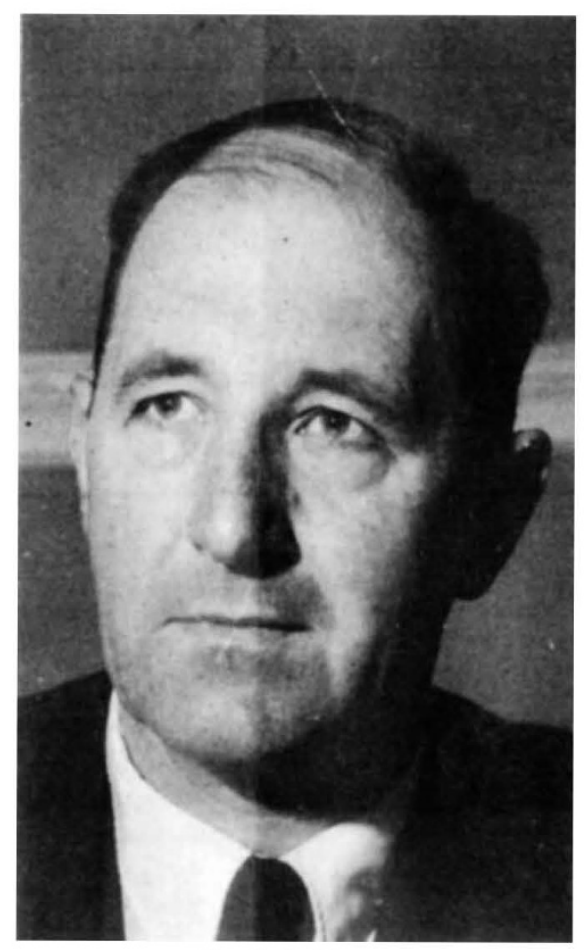

hierarchy of interpreters of research to advanced students".

The research councils and the University Grants Committee should now give consideration to supporting graduate schools in some universities but not in others, says the study group. Research should be financed with this in mind and limited resources should not be diffused "as widely as ... a at present". But the initiative is not to be left entirely in the hands of the research councils and the UGC, and the universities are called upon to initiate some of these changes themselves.

Such radical changes, however, will need to be compensated for. The study group lists two such solutions as follows:

- Academics who are not at centres of research in their subjects must be compensated by providing, and financing, opportunities for them to keep close to the growing points of research and, if they so wish, to come as guest workers to centres of research.

- Implicit value judgments which at present overemphasise achievement in published research as a criterion for a career in university or polytechnic teaching must be modified.

But the essence of the report is that the issues raised need to be discussed. The differing rates of growth of the research and university budgets in the years ahead will ensure that the problems of keeping all university staff members actively involved in "world league" research will increase. getting as good an apprenticeship for research careers as are their fellows in large departments."

The study group points out that there is a case for concentration of resources in centres of research but that this must be balanced by "the need to sustain scholarly standards and enthusiasm among academics in departments which are not designated as centres of research".

For instance, says the study group, research councils might plant viable research units in small departments "even at the risk of depleting any additional resources available to the centres of research". More frequent sabbaticals - perhaps one term free every sevenand an encouragement for staff of small departments to 'migrate' to larger departments as guests could also be a way of resolving the issue.

The unmistakable conclusion which the study group comes to is that in the future there may need to be a significant number of teachers in universities who are not established "in the hierarchy of research workers, but rather in the

\section{£25,000 Prize}

THE MacRobert Award for 1973 has been won by three members of Dunlop Ltd for their development of the Denovo tyre and wheel system. They are Tom French, Eric Mitchell and Reginald Edwards, and they share $f 25,000-$ the largest prize of its kind in the world. It is awarded annually for an outstanding contribution in engineering or the physical sciences enhancing the prestige and prosperity of the United Kingdom.

The Denovo system permits tyres that have blown out or been punctured to be driven for up to 100 miles at up to 50 miles per hour without attention or permanent damage to the tyre, and is beginning to be offered as an option on cars in Britain. 